\title{
Intracranial Grade II Meningioma Oligometastatic to the Cervical Spine
}

\author{
Jyotsna M. Natarajan ${ }^{1}$, Donald E. Born ${ }^{2}$, Griffith Harsh ${ }^{3}$, Lawrence M. Shuer ${ }^{4}$, Scott G. Soltys ${ }^{5}$ \\ 1. Department of Radiation Oncology, Stanford Cancer Institute, Stanford, USA 2. Department of Pathology, Stanford \\ University School of Medicine, Stanford, USA 3. Neurological Surgery, University of California, Davis, Sacramento, USA \\ 4. Department of Neurosurgery, Stanford University Medical Center, Stanford, USA 5. Department of Radiation \\ Oncology, Stanford University School of Medicine, Stanford, USA
}

Corresponding author: Scott G. Soltys, sgsoltys@stanford.edu

\begin{abstract}
For intracranial meningiomas that metastasize extracranially, an oligometastatic state exists that is intermediate between incurable, widely metastatic disease and non-metastatic curable disease. Similar to oligometastatic cancer, aggressive local treatment of meningioma oligometastases is warranted, as it may be curable. We present a patient with multiply recurrent intracranial meningiomas over 19 years, with a transformation from grade I to grade II histology, with oligometastatic disease to the C5 vertebral body. Three years following definitive spinal stereotactic radiosurgery, she remains without evidence of other metastatic diseases. Our case highlights the oncologic concept that metastatic meningioma need not be widely disseminated and provides the clinical rationale for aggressive local treatment of an oligometastatic meningioma.
\end{abstract}

Categories: Radiation Oncology

Keywords: metastases, atypical meningioma, oligometastasis, radiosurgery, spine

\section{Introduction}

Meningiomas are the most common, non-malignant, central nervous system primary tumors [1]. World Health Organization (WHO) grade I meningiomas are considered benign, with a five-year recurrence rate of $7 \%$ to $25 \%$ after a gross-total resection [2]. WHO grade II and III meningiomas are known to be more aggressive in behavior, with recurrence rates between $25 \%$ and $52 \%$ and $50 \%$ and $94 \%$, respectively [2].

Review began 12/09/2020 Review ended 01/15/2021 Published 01/20/2021

\section{๑) Copyright 2021}

Natarajan et al. This is an open access article distributed under the terms of the Creative Commons Attribution License CC-BY 4.0., which permits unrestricted use, distribution, and reproduction in any medium, provided the original author and source are credited.
Extracranial meningioma metastases occur in approximately $0.1 \%$ of all patients with intracranial meningiomas [3]. In case reports [3-8] and small series [2,9] of patients with extracranial spread of meningiomas, metastases typically involve multiple sites, most commonly the lung, liver, lymph nodes, and bone $[10-11]$.

There is growing acceptance that the classical binary concept of metastatic progression, where patients are either widely metastatic and, therefore, incurable versus non-metastatic and curable, is outdated. An intermediate oligometastatic state exists when metastases are localized to a limited number of sites and can potentially be cured with local therapy [12]. Most studies have limited the number of metastases to either one to three or one to five sites to be considered oligometastatic [12-13], but these data are evolving. Local therapy, such as surgery or stereotactic radiosurgery (SRS), to oligometastatic disease can lead to survival rates comparable to patients with a non-metastatic disease [12].

We present a patient with multiply recurrent intracranial meningiomas over 19 years, with a transformation from grade I to grade II histology, who had an oligometastatic disease to the C 5 vertebral body. Three years following spinal surgery and SRS, she remains without evidence of intracranial, spinal, or other metastatic diseases. Our case highlights the oncologic concept that metastatic meningioma need not be widely disseminated and provides the clinical rationale for aggressive local treatment of an oligometastatic meningioma.

\section{Case Presentation}

With institutional research board (IRB) approval, we retrospectively analyzed the treatment and outcomes of a patient who developed oligometastatic spinal metastasis from a multiple recurrent intracranial grade II meningioma.

\section{Initial presentation and treatment: brain surgery \#1 - year 0}

A 34-year-old woman presented with headaches, weakness, and gait instability, which led to the diagnosis of a right frontoparietal parasagittal meningioma. She had a gross total resection, with the pathology of a WHO grade I meningioma. 

diagnosis

Following a seizure, the patient presented to the emergency department with imaging that revealed recurrent meningiomas, a $7 \mathrm{~cm}$ tumor at the vertex obstructing the superior sagittal sinus with an adjacent, separate $0.7 \mathrm{~cm}$ tumor (Figure 1A). These tumors were within and adjacent to the previous site of meningioma and not present on imaging six years prior. She had a bifrontal craniotomy with gross total resection of the tumors. Pathology revealed an atypical meningioma, WHO grade II, composed of a proliferation of cells with ovoid and spindle-shaped mildly pleomorphic nuclei, eosinophilic cytoplasm forming a syncytium, and arranged in poorly formed whorls. Characterization as atypical was based on the finding of up to five mitotic figures per 10 high-power fields (Figure 1B). She had no adjuvant radiotherapy.

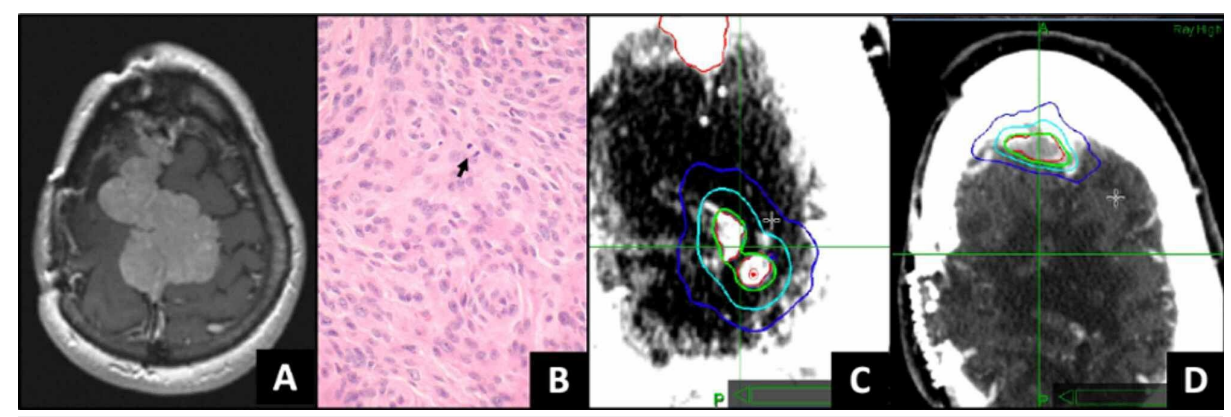

FIGURE 1: Intracranial Meningioma Treatment

A 34-year-old woman had resection of a grade I falcine meningioma (imaging and pathology not available). The tumor recurred 18 years after the initial diagnosis (panel A). A gross total resection revealed transformation to grade II pathology (panel B - 40x magnification) with five mitotic figures (black arrow) per 10 high-power fields - a mitotic figure is noted by the black arrow). Stereotactic radiosurgery (SRS) targeted the recurrent tumor within (panel C - 22 years after initial diagnosis) and distant from (panel D - 26 years after initial diagnosis) the surgical sites of the recurrent tumor. In panels $C$ and $D$, the SRS prescription isodose line of $18 \mathrm{~Gy}$ in one fraction is green, with the $50 \%$ dose line in cyan.

\section{Intracranial recurrence \#2: SRS \# 1 - 22.7 years following initial diagnosis}

Four years later, surveillance magnetic resonance imaging (MRI) demonstrated recurrent disease at three sites (measuring $9 \mathrm{~mm}, 6 \mathrm{~mm}$, and $4 \mathrm{~mm}$ ) within the resection cavity of the recurrent grade II tumor (Figure 1C). These three tumors were treated with 16-18 Gy in one fraction with stereotactic radiosurgery (SRS) (Figure 1D).

\section{Intracranial recurrence \#3: SRS \# 2 - 26 years following initial diagnosis}

Three years later, for progression at another area of dural thickening distant from the original sites of surgery, a $9 \mathrm{~mm}$ tumor was treated with SRS, 20 Gy in one fraction.

\section{Extracranial progression: spine surgery \#1 and spine SRS \#1 - 26.4 years status post initial diagnosis}

While being treated for the intracranial recurrence \#3 above, in the setting of a three-month history of neck pain and stiffness, magnetic resonance imaging (MRI) showed a C5 compression fracture with a tumor in the epidural space encasing the right vertebral artery and extending into the neuroforamen (see Figure $2 \mathrm{~A}$ ), new since prior imaging. The tumor had no intradural extension to suggest that this was a more common intradural, extramedullary spinal meningioma or that this represented cerebral spinal fluid (CSF) spread of her intracranial tumors.

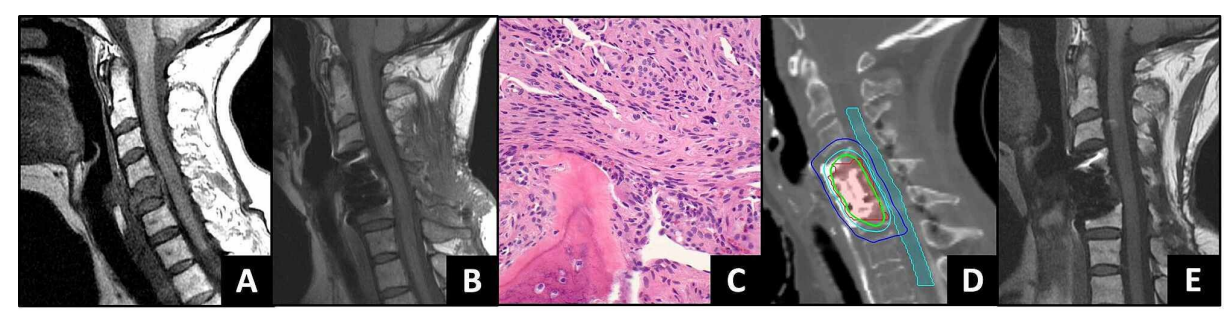

FIGURE 2: Spine Oligometastatic Treatment 


\section{Cureus}

Twenty-six years after her initial diagnosis of a grade 1 intracranial meningioma and eight years following intracranial recurrence as a grade II, she presented with symptomatic C5 metastasis (panel A - sagittal T1 pre-contrast MRI with complete replacement of the vertebral body with pathologic fracture. There was a para-spinous extension into the soft tissue of the neck along the vertebral arteries). Following subtotal resection and stabilization (panel B - post-surgical T1 pre-contrast MRI), pathology revealed a grade II meningioma within the bone (panel C), concordant with the prior intracranial recurrence (in Figure 1B). She had definitive postoperative spinal stereotactic radiosurgery (SRS) to her residual tumor (panel D - spinal SRS plan. 27 Gy in three fractions (green isodose line) targeted the postoperative resection site (red contour)). The spinal cord (blue contour) was limited to a maximum of $21 \mathrm{~Gy}$ (cyan isodose line). Three years following spine SRS, she remains without evidence of spine (panel E), brain, or metastatic progression.

For stabilization and pathologic diagnosis, she underwent a C2-C6 laminectomy with C4-C6 anterior cervical fusion. Pathology revealed atypical meningioma, WHO grade II, within fragments of trabecular bone. The neoplastic proliferation, in addition to showing features typical of meningioma, had areas of sheet-like growth, necrosis, and macronuclei (see Figure 2C). Although mitotic figures were not as numerous, the histology was concordant with the prior intracranial recurrence \#1 (Figure 1B). She was treated with postoperative spinal SRS, $27 \mathrm{~Gy}$ in three fractions, to the C4, C5, C6 vertebral bodies and the extraosseous extension along the right vertebral artery from C4 to C7 (Figure 2D).

\section{Follow-up: 30.5 years following initial diagnosis}

Three years following SRS of the spinal metastasis, she remains locally controlled in both her brain and spine. Surveillance body computed tomography (CT) imaging has displayed no evidence of other metastatic sites.

\section{Discussion}

Meningiomas are the most common primary central nervous system tumor, accounting for approximately $38 \%$ of all brain tumors and $53 \%$ of all non-malignant brain tumors [1]. Approximately $25 \%$ of meningiomas are WHO grade II [1,14]. Following a gross total surgical resection, tumor local recurrence rates are between $7 \%$ and $25 \%$ for WHO grade I histology and up to $52 \%$ for WHO grade II meningiomas [2-3,15].

Despite a high local recurrence rate for grade II meningiomas, extracranial metastases are extremely rare, occurring in approximately $0.1 \%$ of patients [16]. Multiple case series of metastatic meningioma (see Table 1), including the largest recent report of six patients by Kessler et al., suggest that once a meningioma has hematogenously spread to develop metastases, it can behave similarly to hematogenously disseminated cancer, with metastatic involvement of multiple extracranial sites, including the spine, bones, liver, and lungs. In the selected series in Table $1,77 \%$ of patients with extracranial spread of meningioma had the involvement of more than a solitary site at the time of diagnosis of metastatic disease. 


\section{Cureus}

\begin{tabular}{|c|c|c|c|c|c|c|c|c|}
\hline Citation & $\begin{array}{l}\text { Number } \\
\text { of } \\
\text { patients } \\
\text { reported }\end{array}$ & $\begin{array}{l}\text { Location of } \\
\text { original tumor }\end{array}$ & $\begin{array}{l}\text { Time from original } \\
\text { diagnosis to } \\
\text { extracranial } \\
\text { metastasis }\end{array}$ & Tumor grade & $\begin{array}{l}\text { Number of } \\
\text { metastatic } \\
\text { sites }\end{array}$ & $\begin{array}{l}\text { Location of } \\
\text { metastatic sites }\end{array}$ & $\begin{array}{l}\text { Length of } \\
\text { follow-up after } \\
\text { time of } \\
\text { metastases }\end{array}$ & Status \\
\hline $\begin{array}{l}\text { Abboud } \\
2009 \\
{[10]}\end{array}$ & 1 & Left tentorium & 13 years & II & 2 & $\begin{array}{l}\text { Left and right } \\
\text { sacroiliac and gluteus } \\
\text { muscle regions }\end{array}$ & Not reported & $\begin{array}{l}\text { Alive without } \\
\text { disease } \\
\text { progression }\end{array}$ \\
\hline $\begin{array}{l}\text { Kessler } \\
2017 \text { [2] }\end{array}$ & 1 of 4 & Falcine & 14 years & $\begin{array}{l}\text { l, transformed to II } \\
\text { when metastasized }\end{array}$ & 1 & Lung & $\begin{array}{l}\text { Hospice after } 1 \\
\text { year }\end{array}$ & Deceased \\
\hline $\begin{array}{l}\text { Kessler } \\
2017 \text { [2] }\end{array}$ & 2 of 4 & $\begin{array}{l}\text { L parietal, R } \\
\text { frontoparietal } \\
\text { lobes }\end{array}$ & 23 years & $\begin{array}{l}\text { Originally II, } \\
\text { transformed to III } \\
\text { intracranially before } \\
\text { metastasis }\end{array}$ & 2 & Lung, Mediastinum & $\begin{array}{l}\text { Hospice after } 4 \\
\text { years }\end{array}$ & Deceased \\
\hline $\begin{array}{l}\text { Kessler } \\
2017 \text { [2] }\end{array}$ & 3 of 4 & $\begin{array}{l}\mathrm{L} \text { frontal, } \mathrm{L} \\
\text { hemisphere } \\
\text { extending to } \\
\text { calvarium }\end{array}$ & 6 years & $\begin{array}{l}\text { Originally II, } \\
\text { transformed to III } \\
\text { intracranially before } \\
\text { metastasis }\end{array}$ & 2 & Liver, Spine & 11 months & Deceased \\
\hline $\begin{array}{l}\text { Kessler } \\
2017 \text { [2] }\end{array}$ & 4 of 4 & $\begin{array}{l}\text { Superior } \\
\text { sagittal sinus }\end{array}$ & 7 years & II & 1 & Liver & $\begin{array}{l}\text { Hospice after } 3 \\
\text { weeks }\end{array}$ & Deceased \\
\hline $\begin{array}{l}\text { Lee } \\
2009 \text { [4] }\end{array}$ & 1 & $\begin{array}{l}\text { Right lateral } \\
\text { ventricular }\end{array}$ & 14 months & II, transformed into III & 8 & $\begin{array}{l}\mathrm{T} 5, \mathrm{~T} 7, \mathrm{~T} 10, \mathrm{~L} 1, \mathrm{~L} 3 \text {, } \\
\mathrm{L} 4, \mathrm{~S} 1 \text {, and } \mathrm{S} 2 \\
\text { vertebrae of the spine }\end{array}$ & 1 month & $\begin{array}{l}\text { Deceased after } \\
1 \text { month }\end{array}$ \\
\hline $\begin{array}{l}\text { Olson } \\
1994[5]\end{array}$ & 1 & Left frontal lobe & 17 months & II & 4 & $\begin{array}{l}\text { T6, T11, pulmonary } \\
\text { and hilar nodes }\end{array}$ & N/A & N/A \\
\hline $\begin{array}{l}\text { Paix } \\
2017[6]\end{array}$ & 1 & $\begin{array}{l}\text { Right parietal } \\
\text { lobe }\end{array}$ & 3 months & II & 8 & $\begin{array}{l}\text { T8, T10, L1, L4, } 8^{\text {th }} \\
\text { rib, coccyx, lungs, } \\
\text { and liver }\end{array}$ & Not Reported & $\begin{array}{l}\text { Alive with } \\
\text { metastases }\end{array}$ \\
\hline $\begin{array}{l}\text { Palmer } \\
1994[7]\end{array}$ & 1 & $\begin{array}{l}\text { Right posterior } \\
\text { fossa }\end{array}$ & 12 years & II & 2 & $\begin{array}{l}\text { L5 extending into the } \\
\text { right pedicle, Lung }\end{array}$ & $\begin{array}{l}\text { Hospice for an } \\
\text { undisclosed } \\
\text { period }\end{array}$ & $\begin{array}{l}\text { Deceased after } \\
6 \text { months }\end{array}$ \\
\hline $\begin{array}{l}\text { Pinsker } \\
2005[8]\end{array}$ & 1 & $\begin{array}{l}\text { Right frontal } \\
\text { lobe }\end{array}$ & 5 years & II & 2 & $\begin{array}{l}\text { C3 and C4 vertebral } \\
\text { bodies }\end{array}$ & Not Reported & $\begin{array}{l}\text { Alive with } \\
\text { metastases }\end{array}$ \\
\hline $\begin{array}{l}\text { Singh } \\
2016 \text { [9] }\end{array}$ & 1 of 2 & $\begin{array}{l}\text { Left middle } \\
\text { cranial fossa }\end{array}$ & 3 years 4 months & $\mathrm{II}$, transformed to III & 4 & $\begin{array}{l}\mathrm{L} 4, \mathrm{~T} 7, \mathrm{~T} 8, \mathrm{~T} 9, \mathrm{~T} 10 \text {, } \\
\text { S2 to left upper } \\
\text { sacral foramina, } \\
\text { spinal cord }\end{array}$ & 5 months & $\begin{array}{l}\text { Deceased } 5 \\
\text { months after } \\
\text { finding } \\
\text { metastases }\end{array}$ \\
\hline $\begin{array}{l}\text { Singh } \\
2016[9]\end{array}$ & 2 of 2 & $\begin{array}{l}\text { Right frontal } \\
\text { lobe }\end{array}$ & 6 years & I, transformed into II & 9 & $\begin{array}{l}\text { Multiple vertebrae, } \\
\text { distal left clavicle, } \\
\text { proximal left humerus }\end{array}$ & 1 year & $\begin{array}{l}\text { Deceased } 1 \\
\text { year after } \\
\text { finding } \\
\text { metastases }\end{array}$ \\
\hline $\begin{array}{l}\text { Current } \\
\text { Case }\end{array}$ & 1 & $\begin{array}{l}\text { Right frontal } \\
\text { parasagittal } \\
\text { lobe }\end{array}$ & 26 years & $\begin{array}{l}\text { I, transformed into II } \\
\text { prior to extracranial } \\
\text { metastasis }\end{array}$ & 1 & C5 vertebral body & 3 years & $\begin{array}{l}\text { Alive, with no } \\
\text { evidence of } \\
\text { disease }\end{array}$ \\
\hline
\end{tabular}

\section{TABLE 1: Reported cases of extracranial metastases of WHO grade II atypical meningiomas}

Adapted from Kessler et al. [2], Ward et al. [3]

Historically, the state of a patient's cancer has been categorized into two groups: locally confined and potentially curable or widely metastatic and incurable. In 1995, Hellman and Weichselbaum proposed an intermediate state between locally confined and widely metastatic [17]. This oligometastatic state, where a limited number of metastatic sites are present prior to developing widely disseminated metastases, may be curable with definitive local treatment of each oligometastasis [12-13]. Consensus recommendations and a proposed classification of the various oligometastatic states were recently published [18]. 
There are no clear risk factors associated with why some patients may develop disseminated metastatic meningiomas compared to patients with oligometastatic disease as in our case example. Retrospective [19] and prospective [20] data find that recurrent meningiomas behave more aggressively than newly diagnosed meningiomas of the same grade. One may hypothesize that the more aggressive behavior of locally recurrent tumors increases the risk of hematogenous dissemination; all of the previously reported cases of metastatic meningioma [2] occurred following a local recurrence of the primary tumor.

Despite multiple intracranial recurrences in our patient, the transformation to a higher grade, and subsequent metastasis, one may still hypothesize that the very long disease-free intervals between recurrences connote less aggressive behavior than recurrent tumors seen in other patients. The outcome of our patient is not necessarily notable for durable local control of her metastatic site with spinal radiosurgery; ablative radiotherapy is a standard of care treatment for oligometastatic disease. Unusual is her oligometastatic presentation, with no further evidence of recurrence in three years of follow-up. Of note, she did not receive any systemic agents that could decrease the risk of further metastatic disease.

The oligometastatic state exists for cancer that has metastasized. We believe that our patient demonstrates that the oligometastatic state can apply to metastatic meningioma. As seen in Table 1, once metastatic, at least $77 \%$ of patients have widespread metastases at multiple sites. Our patient had a solitary extracranial metastasis to the C5 vertebral body, treated with surgical stabilization and definitive spinal radiosurgery. Three years following her initial metastatic disease, she has local control within the brain and spine, with no further extracranial metastases.

\section{Conclusions}

The oligometastatic state exists for patients with metastatic meningioma. As with metastatic cancer, the oligometastatic state is potentially curable, with definitive local treatment of metastatic sites. Our case report serves to give hope to patients with oligometastatic extracranial spread of intracranial meningiomas.

\section{Additional Information \\ Disclosures}

Human subjects: Consent was obtained or waived by all participants in this study. Conflicts of interest: In compliance with the ICMJE uniform disclosure form, all authors declare the following: Payment/services info: All authors have declared that no financial support was received from any organization for the submitted work. Financial relationships: All authors have declared that they have no financial relationships at present or within the previous three years with any organizations that might have an interest in the submitted work. Other relationships: Dr. Soltys: Consultant for Inovio Pharmaceuticals, Inc., speaker for Zap Surgical, Inc. The other authors declare no conflicts of interest.

\section{References}

1. Ostrom QT, Cioffi G, Gittleman H, Patil N, Waite K, Kruchko C, Barnholtz-Sloan JS: CBTRUS statistical report: primary brain and other central nervous system tumors diagnosed in the United States in 2012-2016. Neuro Oncol. 2019, 21:1-100. 10.1093/neuonc/noz150

2. Kessler RA, Garzon-Muvdi T, Yang W, et al.: Metastatic atypical and anaplastic meningioma: a case series and review of the literature. World Neurosurg. 2017, 101:47-56. 10.1016/j.wneu.2017.01.070

3. Ward AL, Risman A, Segar S, Sharma S, Vender JR: Atypical intracranial meningioma with metastasis to C7 vertebral body: a case report. World Neurosurg. 2019, 122:593-598. 10.1016/j.wneu.2018.11.067

4. Lee GC, Choi SW, Kim SH, Kwon HJ: Multiple extracranial metastases of atypical meningiomas . J Korean Neurosurg Soc. 2009, 45:107-111. 10.3340/jkns.2009.45.2.107

5. Olson PN, Mitchell SL, Goswitz J, Griffiths HJ: Case report 853. Meningioma metastatic to the spine . Skeletal Radiol. 1994, 23:405-407. 10.1007/BF02417004

6. Paix A, Waissi W, Antoni D, Adeduntan R, Noël G: Visceral and bone metastases of a WHO grade 2 meningioma: a case report and review of the literature [Article in French]. Cancer/Radiothér. 2017, 21:5559. 10.1016/j.canrad.2016.09.012

7. Palmer JD, Cook PL, Ellison DW: Extracranial osseous metastases from intracranial meningioma . Br J Neurosurg. 1994, 8:215-218. 10.3109/02688699409027971

8. Pinsker MO, Buhl R, Hugo HH, Mehdorn HM: Metastatic meningioma WHO grade II of the cervical spine: case report and review of the literature [Article in German]. Zentralblatt Für Neurochir. 2005, 66:35-38. $10.1055 /$ s-2004-836245

9. Singh R, Ryan C, Chohan MO, Tisnado J, Hadjigeorgiou GF, Bilsky MH: Intracranial meningioma with vertebral or intraspinal metastasis: report of 2 cases and review of the literature. J Neurosurg Spine. 2016, 25:775-781. 10.3171/2016.5.SPINE151457

10. Abboud M, Haddad G, Kattar M, Aburiziq I, Geara FB: Extraneural metastases from cranial meningioma: a case report. Radiat Oncol Lond Engl. 2009, 4:20. 10.1186/1748-717X-4-20

11. Vakil H, Tran L, Lewis GD, Cykowski MD, Bulter EB, Teh BS: Biopsy proven metastatic meningioma: Aa case report and review of the literature. Rep Pract Oncol Radiother. 2019, 24:528-532. 10.1016/j.rpor.2019.08.002

12. Otake S, Goto T: Stereotactic radiotherapy for oligometastasis. Cancers. 2019, 11:133. 10.3390/cancers 11020133

13. Palma DA, Salama JK, Lo SS, Senan S, Treasure T, Govindan R, Weichselbaum R: The oligometastatic state separating truth from wishful thinking. Nat Rev Clin Oncol. 2014, 11:549-557. 10.1038/nrclinonc.2014.96 


\section{Cureus}

14. Louis DN, Perry A, Reifenberger G, et al.: The 2016 World Health Organization classification of tumors of the central nervous system: a summary. Acta Neuropathol. 2016, 131:803-820. 10.1007/s00401-016-1545-1

15. Walcott BP, Nahed BV, Brastianos PK, Loeffler JS: Radiation treatment for WHO grade II and III meningiomas. Front Oncol. 2013, 3:227. 10.3389/fonc.2013.00227

16. Adlakha A, Rao K, Adlakha H, Perry A, Crotty TB, Scheithauer BW, Ryu JH: Meningioma metastatic to the lung. Mayo Clin Proc. 1999, 74:1129-1133. 10.4065/74.11.1129

17. Hellman S, Weichselbaum RR: Oligometastases. J Clin Oncol. 2016, 13:8-10. 10.1200/JCO.1995.13.1.8

18. Guckenberger M, Lievens $\mathrm{Y}$, Bouma AB, et al.: Characterisation and classification of oligometastatic disease: a European Society for Radiotherapy and Oncology and European Organisation for Research and Treatment of Cancer consensus recommendation. Lancet Oncol. 2020, 21:18-28. 10.1016/S1470-2045(19)30718-1

19. Mirimanoff RO, Dosoretz DE, Linggood RM, Ojemann RG, Martuza RL: Meningioma: analysis of recurrence and progression following neurosurgical resection. J Neurosurg. 1985, 62:18-24. 10.3171/jns.1985.62.1.0018

20. Rogers CL, Won M, Vogelbaum MA, et al.: High-risk meningioma: initial outcomes from NRG Oncology/RTOG 0539. Int J Radiat Oncol. 2020, 106:790-799. 10.1016/j.ijrobp.2019.11.028 